\title{
The Challenges of the Implementation of Paragraph 1 of Article 6 of the European Convention on Human Rights and Fundamental Freedoms in the Judicial System of the Republic of Macedonia
}

\author{
Emine Zendeli ${ }^{1}$ \\ ${ }^{1}$ Faculty of Law, South East European University, Tetovo, Ilindenska nn 1200, Macedonien \\ Correspondence: Emine Zendeli, Faculty of Law, South East European University, Tetovo, Ilindenska nn 1200, \\ Macedonien. Tel: 3-894-435-6141.E-mail: e.zendeli@seeu.edu.mk
}

Received: February 5, 2013 Accepted: March 7, 2013 Online Published: May 30, 2013

doi:10.5539/jpl.v6n2p193 URL: http://dx.doi.org/10.5539/jpl.v6n2p193

\begin{abstract}
In the European Convention on Human Rights and Fundamental Freedoms (ECHRFF). it is guaranteed the right of trial within a reasonable time frame. Since the Republic of Macedonia (R.M)is part of this Convention, it is obliged, to guarantee the right of realizing the rights and obligations of citizens in "reasonable terms." The Ratification of the Convention has made space for the citizens of the Republic of Macedonia, who consider that with excessive dragging of proceedings are violated the right to trial within a reasonable time and they may initiate a lawsuit in the European Court of Human Rights (ECHR) in Strasbourg. This court has found frequent violations of this right, and due to that has forced the R.M to compensate damage to citizens, who have been violated the right to trial within a reasonable time. In this context, the purpose of effective protection of human rights and fundamental freedoms, and in order to avoid negative consequences that can be caused to the state, if citizens in a large number address to the ECHR, The R.M has stepped up efforts to increase the efficiency of the courts, and to ensure that the right of citizens is guaranteed by the European Convention.
\end{abstract}

Keywords: ECHRFF, ECHR, trial within a reasonable time

\section{Introduction}

In the European Convention on Human Rights and Fundamental Freedoms (ECHR), the principle of trial within a reasonable time, is elevated to the level of basic human rights. After the independence of the Republic of Macedonia and the articulation of its aspiration for integration into the European Union, followed various activities in order to harmonize the legislation of the Republic of Macedonia with the European standards. The Republic of Macedonia has signed the Convention on the rights and fundamental freedoms, and as a result has an obligation from (Article 6 para. 1.) of this Convention, to guarantee the right of realization of civil rights and obligations of citizens in reasonable terms, as one of the basic conditions for its integration into the European Union. The above provisions, according to which everyone is entitled to a fair and public hearing within a reasonable time at independent and impartial court established by law, obliges the signatory states to organize efficient judicial system, where the courts will be able to guarantee citizens the right to bring up merit verdicts within a reasonable time.

The Ratification of the Convention by the Parliament of the Republic of Macedonia has made it possible, that its citizens, who claim that its violated the right to trial within a reasonable time, to may address it to the European Court of Human Rights.

The issue of the duration of the proceedings, namely, the right to trial within a reasonable frame time has been treated in the national legislation of the Republic of Macedonia. Thus, the provisions of the Law on Courts of the Republic of Macedonia, it is said that every citizen has the right to a fair and public hearing within a reasonable time at an independent and impartial tribunal established by law. (Note 1) Even the Law on Civil Procedure requires courts to conduct proceedings within a reasonable time, with as little expense, as well as to prevent any abuse of the rights of the parties in the proceedings". (Note 2)

The right to trial within a reasonable time has become part of the strategic plan of the Ministry of Justice of the Republic of Macedonia for the period 2012-2014, which aims to meet the conditions which must be meet in RM in its way towards the European Union. (Note 3) 


\section{The Right to Trial within a Reasonable Time}

The Trial within a reasonable time is standard, which the court considers according to prescribed manner in any concrete case. (Note 4) Adhering to the standard of "trial within a reasonable time" is imposed on dual interest, in the interest of the people with whom it has to do directly, as well as for general legal security interest. (Note 5) The evaluation of the duration of the term, ie, whether a term is reasonable or not, is estimated in each case. The time which is calculated as a reasonable term starts from the moment of initiation of appropriate proceedings, until its completion in the highest instance. According to the practice of the European Court of the need for a trial within a reasonable time, does not include only the period of judicial decision-making, which only establishes the rights of citizens in the procedure, but also the procedure of execution of court decisions.

In case of a request for arbitration within a reasonable time, the European Court of Human Rights takes into account the specific circumstances of the case as follows: a) the complexity of the case; b) the position of the applicant; c) position of power; $d$ ) the nature of the dispute.

How an issue is complex is evaluated taking into account all aspects of the case, which must be resolved. The complexity of the matter may be referred to as factual as well as legal. In some cases the existence of complex issues it is justified the delay of the procedure. (Note 6)

If the dragging of the procedure is caused by the applicant itself, he/she has no right to invoke the violation of the right to trial within a reasonable time. However, it can not be used against him, ie, can not affect the damage of his position as party in procedure.

If the delay in court proceedings is caused by administration or judicial authorities, it is the responsibility of the State. So, although the judiciary bears the greatest responsibility for ensuring speedy completion of the procedure, however, it is the state, which is responsible for all its organs. The Court in Strasbourg issues does not implied in establishing facts about which organ of the state is responsible for non-compliance with international obligations, but this is in charge of the state.

Regarding the type of dispute, the court is required to be efficient when regarding the procedures which has special significance for the presenter of the complaint, has special specifications, or character of permanent loss of right. This mostly has to do with cases when it deciding on the position of children, elderly or disabled persons, concerning damage compensation for bodily injuries, cases of labor relations etc.. (Note 7)

\section{The Goal of Applying the Principle of Trial within a Reasonable Time}

The regulations for trial within a reasonable request from the judge during the case resolution practice to have the intention of respecting procedural and substantive legal provisions, but also to try his/her intention to be achieved in the shorter period of time, so that entity that seeks the justice and legal protection, to obtain it as soon as possible (efficient justice). Accordingly, the right to trial within a reasonable time is the right in quick justice (efficient), but also justice (legal).

The legal dilemma poses the question of whether the length of the proceedings (the process of realization of the right) is to be determined exactly on time, or it is enough the legal standard, the trial within a reasonable time. " In favor of defining the term speaks of the fact that the lack of time represents real risk of bypassing the goal of this institute. (Note 8)

There are opinions that the trial within a reasonable time, ie the definition of strict deadlines (Note 9) may adversely affect on the independence of the judge who is planning the time of trial. However, it seems as more acceptable opinion, according to which the judge continues to be completely independent in reaching a decision, although he/she should bring the verdict within a specified period correct.

In the legal system of the Republic of Macedonia, the legislator has not practiced determining the exact time of the trial (although some procedures are said to be urgent, eg labor relations procedures). However, I think that in our court system too must be respected legal standard of "trial within a reasonable time" as an achievement of the civilized world of legal culture, which responds to the legal security of every citizen, but the size of this standard should be determined taking into account the specific situation in our judiciary, where: 1.courts are still burdened with a large number of pending cases, 2. judges have no conditions for work, 3. We have structural barriers in society and judicial apparatus, which generate the appearance of a large number of remained cases, which hinder performance in other cases, 4 . There is a lack of level of legal culture of participants in the trial. In such conditions, the state is spending large amounts of money in the name of compensation for the violation of the right to trial within a reasonable time frame. If these funds would be spent for the promotion of cadres, the renovation of court facilities, arranging spaces in the courts, computerization, etc.. we would not have this situation that we have now. 


\section{The Right of Trial within a Reasonable Time in the Positive Law of the Republic of Macedonia}

Although the right of trial within a reasonable time, is regarded as one of the most important legal and political issues, set from the European Convention for the courts of the country, however, this legal standard is not explicitly protected by the Constitution of the Republic of Macedonia . Despite this fact, this principle obliges directly our judicial system, because any of international agreement ratified under the Constitution is considered part of the internal legal order, and according to the judicial effect it stands above the law. (Note 10) In Section 50. para. 1. of the Constitution of the Republic of Macedonia, it is defined the right of citizens to protect their legal rights to realize before the regular courts, and before the Constitutional Court they can realize only those rights that are explicitly listed in Article 110 para. 3, (Note 11) which however does not include the right of trial within a reasonable time. From above mentioned, it can be concluded that the Constitutional Court of the Republic of Macedonia has "restrictive competence" regarding the protection of fundamental rights and freedoms, even it protects only those rights that are expressly stated in this provision, and not all the rights and freedoms guaranteed by the Constitution. With this provision the constitutional rights of citizens are violated. They are deprived of the right to lodge an action to protect the constitutional right (Note 12) for a trial within a reasonable time. If they had the right to initiate constitutional petition before the Constitutional Court, it would be just one more legal tool for investigating violations of their rights (and the right of trial within a reasonable time), and will undoubtedly affect reducing the number of appeals before the European Court. (Note 13)

In European democratic countries, where rapid decision-making principle is almost universal disregard of the right to trial within a reasonable time often is presented as a reason for initiating constitutional claim. (Note 14) Thus, in cases where there is a suspicion that the regular courts will not respect the principle of trial within a reasonable time, and this would violate the constitutional rights of citizens, it is available to the citizen's constitutional claim. (Note 15) If the Constitutional Court acting under constitutional claim states that it is a violation of the principle of trial within a reasonable time, it is likely that by the decision, assign a deadline for choosing a merits case by the ordinary court. This period will start running from the date of notification of the decision of the Constitutional Court. Thus in the provisions of the German Constitution it is stated that: every citizen who claims that the act of a state body, whether federal or provincial (legislative, executive or judicial) has violated any of his/her fundamental rights guaranteed by the Federal Constitution, has the right to submit a claim to the Federal Court ".(Note 16) Otherwise, Germany has no specific law regulating the right to trial within a reasonable time, but the triel institute within a reasonable judgment (angemessene Verfahrensdauer) is derived from (art. 4. Article 19) of the Constitution. (Note 17)

The right to file suit to protect the constitutional right for a trial within a reasonable time frame is provided in the Croatian Constitution, which states that "citizens have the right to file a lawsuit to protect the constitutional rights and freedoms determined by the Constitution" specifically with (Article 29) of the Constitution, which states that "everyone has the right to an independent and impartial tribunal, in a fair and reasonable deadline to decide on the rights and obligations, or his criminal responsibility."

The constitutional right to lodge the claim is set forth in the Constitution of Slovenia (160. Drops. 6), (Note 18) in the Albanian Constitution, (Note 19) etc.

\subsection{The Right to Trial within a Reasonable Time to the Law on Courts of the Republic of Macedonia}

The right to trial within a reasonable time in the legal system of the Republic of Macedonia is regulated by the provisions of the Law on Courts (2006), respectively, in the most concrete way with the provisions of the Law on Changes and Amendments to the Law on Courts (2008).

Law on Courts (2006) does not define the right for trial within a reasonable time frame, but, however, it recognizes this legal standard. Thus, in accordance with the provisions of this law, the party that considers that a competent court has violated the right for trial within a reasonable time frame, has the right to submit application to the high court, which is required within six months of submission of the request, to decide whether the lower court violated the law in question. If it finds a violation of the right for a trial within a reasonable time by the relevant decision will determine compensation for the requesting party (compensation falls on the court's budget).

Procedural tool, determined by the provisions of the Law on Courts (2006), unfortunately, remained in the frame of a dysfunctional attempt to regulate this institution. It was unjustified, even more so when the issue of the trial within a reasonable time had become part of domestic law, since, a period of time had already spent since the Republic of Macedonia has ratified the European Convention for human rights and fundamental freedoms.

The Law on amendments to the Law on Courts (2008), which came as a result of evolving the will of the legislator, but obviously the European political and diplomatic pressure, in particular, the European Court of Human Rights, 
created a more operationalized model of procedural tool to protect the right of trial within a reasonable time frame. This law explicitly stressed the need to follow the rules and principles established by the European Convention, and the experience of the European Court of Human Rights". (Note 20) This law has also given the exclusivity of the Supreme Court to decide on the right for trial within a reasonable time frame. (Note 21) Based on changes and amendments to the mentioned law: "The demand for protection of the right for trial within a reasonable time may be submitted during the proceedings at the state courts, and no later than six months from the date the decision becomes final." It should contain: 1 / information of the applicant and his legal representative; 2 / information on the subject of the trial and the procedure during which the party considers the violation of the right for trial within a reasonable time has occured; 3 / justification for the reasons for which is a violation of the right for trial within a reasonable time; 4 / statement of cash compensation, and 5 / signature of the applicant.

The Supreme Court, immediately after receipt of the request or at the latest within 15 days will request from the first instance court to provide description of the acts of the case file and, where appropriate, the statement by the Supreme Court for the duration before its procedure. (Note 22) Otherwise, the Supreme Court of the Republic of Macedonia is obliged within six months of the submission of the request to act upon it, and decide whether the lower court had violated the right for trial within a reasonable time, always taking into account the rules and principles of the European Convention and the law practice of the European Court. " Regarding the request for protection of the right for trial within a reasonable time, the Supreme Court decides in a trial panel of three judges in a closed session, in exceptional case, the court may hear the applicant and the representative of the court whose proceedings is the subject of a filed claim. " During the process of establishing about violation of the right for trial within a reasonable time, the Court takes into account: 1 . Complexity of the issue, 2 . conduct of the parties, and the court 3. Conduct of the court that prosecuted the case. (Note 23)

If the Supreme Court determines that a violation of the right for trial within a reasonable time by the decision will set a time within which the court where the case is being proceding the case, shall decide on the request for trial within a reasonable time, while for the applicant will determine the monetary compensation. Compensation that should be given to the applicant, affects the court's budget, and must be paid within three months from the day of the decision of the Supreme Court. (Note 24) Against the decision of the Supreme Court, the aggrieved party has the right to appeal, within eight days from the date of receipt of the decision.

The appeal will be decided by the Supreme Court, as a court of competent jurisdiction located in the second degree against decisions of the court's own troops, when it is prescribed by law "(Article 35. Paragr.1., Item 1). (Note 25)

4.2 The Implementation of the European Convention for the Protection of Human Rights and Fundamental Freedoms and the Trial within a Reasonable Time

On 10.04.1997, the Parliament of the Republic of Macedonia ratified the European Convention on human rights and fundamental freedoms. As according to the provisions of the Constitution of the Republic of Macedonia, the International Conventions have the status of a national source, consequently, national courts are obliged to respect the standards set by them. (Note 26) The trial within a reasonable time frame represents the legal standard, which is guaranteed by the courts of the Republic of Macedonia, which are obliged to proceed within a reasonable procedures, to the contrary, any unreasonable delay of the proceedings will be considered a violation of the Convention, and will result in the party's right to turn to the European Court with a request for protection of the right for trial within a reasonable time frame. The requirements for the protection of this right will be processed by the European Court of Human Rights, only after they have consumed protective tools within the domestic legal system, on the contrary, the application will be rejected as inadmissible. (Note 27)

The European Court of Human Rights stipulates sanctions for lasting procedures, which have after the ratification of the Convention. But in addition, the court has paid special attention to a group of important perennial procedures, initiated before the ratification of the Convention, which last even after its ratification, the so-called "transition cases". Regarding these cases there is a responsibility of the state for the duration of the procedure after the ratification of the Convention. (Note 28)

Inefficiencies measures to protect the right for trial within a reasonable time, within the legal system of the Republic of Macedonia, has resulted in a large number of complaints against the Republic of Macedonia before the European Court by its citizens.

The European Court has informed us about the lack of effective measures, among others in the decision on case Bajallxhiev against RM. (Note 29) In Bajallxhiev case against RM, the complainant refers to a breach of Article 6 . para. 1 of the European Convention, alluding to the unjustified delay of civil proceedings (the lawsuit was filed in 1996) and Article 13 of the European Convention, which provided effective measures for the protection of human rights and freedoms. In this case, the European Court of Human Rights, when deciding on the violation of the right 
for trial within a reasonable time, the judgment concluded a violation of Article 13 of the Convention which provides that: any person who has violated the rights and freedoms guaranteed by the Convention shall have an effective legal tools for their protection before national bodies, regardless, that the offense is committed in the proceedings of official duties. "

The legal measure would be effective in the sense of Article 13 of the European Convention, if you manage to avoid the violation of rights and freedoms, namely, to influence in bringing faster decision by the body that acts in connection with the case, or provide appropriate compensation if they have already been breached. In the legal system of the Republic of Macedonia there is not yet an effective measure regarding complaints against the violation of the right for a trial within a reasonable time, it is also the main reason that affects the number of its citizens' complaints before the European Court.

Prior complaints against RM by its citizens before the European Court were filed in 1999, and continued with a heady growth trend. Thus, in 1999, were presented (31) complaints in 2001 (59), in 2003 (148) 2005 (234), in 2006 (343) 2007 (454) in 2011 (376). (Note 30) The total number of complaints against the Republic of Macedonia from 1999 to 31.12.2011 is 3181 complaints, of which 1955 were rejected as non-justified. Of the total number of claims against the Republic of Macedonia, $65 \%$ of them were addressed to the European Court of Human Rights on the protection of the right for a trial within a reasonable time.

In the practice of the European Court it is created a new experience, as the way of resolving cases. Thus available to the parties is agrrement, or the so-called (friendly settlement), and the unilateral declaration. (Note 31) For claims filed in 2007, the court at the beginning of the procedure provides the parties with opportunity for reconciliation, with the signing of the declaration, according to which parties are bind with respective obligations, eg the Government of the Republic of Macedonia, takes the obligation to pay certain amount of money to the applicant, and the applicant is obliged to waive any claim against RM, accepting that presented reconciliation resolves the merits of the case. An example of reconciliation is Janeva case against the Republic of Macedonia, (Note 32) which was initiated with the aim of protecting the right for trial within a reasonable time frame. This case before the European Court trial for human rights ended in friendly agreement. The RM, through an agent of the Government took the obligation within three months from the date of receipt of the decision, to pay a sum of 77,000 - $€$ in the name of material and immaterial damage compensation, as well as the costs of the proceedings before the domestic courts. The complainant accepted the proposal, renounced any claim to the RM, and stated that this was a merit of the case.

The large number of complaints from citizens, who before the European Court of human rights and fundamental freedoms contested the lasting of the proceedings before the domestic courts and seek protection of the principle of reasonable judgment, for years (1999-2011) has resulted in loading of the budget of the Republic of Macedonia to $€ 1,250,699$. (Note 33)

\section{Activities Undertaken in the Context of Ensuring the Principle of Trial within a Reasonable Time}

One of the fundamental goals in the context of judicial reform of RM is to increase the efficiency of the courts and reduce the number of pending cases. In this regard, in the previous period were permanently taken various measures and activities in the legislative as well as in the organizational and operational plan. As a result of many activities in recent years we have witnessed increasing the efficiency of the courts in the Republic of Macedonia.

In the Courts of the Republic of Macedonia in 2010 were received a total of 197,194 new cases, or 23\% less than in 2006 , and from them only 94,145 were resolved, respectively, $11 \%$ more than in 2006 . In all courts the number of pending cases has decreased by 183,543 cases, respectively, to $22 \%$ in comparison with 2006 . In 2010 , the courts have resolved 967,352 cases. The number of solved cases in 2010 compared to 2009 increased by 328,329 cases or to record achievement of $52 \%$. This speaks to the efficiency of the courts, while in decades there has been a significant increase in the number of pending cases. (Note 34)

Increasing the efficiency of the courts and respect for the right for a trial within a reasonable time frame is dedicated to improving the procedural legal framework, such as the Law on Civil Procedure, the Law on contentious proceedings, Law Enforcement and the Law on Courts .

By the provisions of the Law on Courts was reorganized the judicial system of RM. (Note 35) Under this law, the Courts decide only in the first instance on the claim. They can act as courts with basic competence, and as courts with expanded competencies, while appellate courts do not act in the first instance in the suit, as it used to be done before, but, just as courts of second instance, according to the complaint.

The support of the Supreme Court of the Republic of Macedonia to the rules and principles of the European Convention and the practice of the European Court is a powerful indicator of the development of legal cases on the 
judiciary of the Republic of Macedonia, and in creating a positive opinion to the European Court, as the implementation of the rules and principles of the European Convention and the law cases of the European Court by the highest court in the RM (European Court of Justice decisions present the source of law in the legal order of the European Union and as such are binding ). This may affect to prove the effectiveness of domestic measures for the protection of the right for trial within a reasonable time frame. If the legal measues are not considered effectively by the European Court the parties are entitled to apply to the European Court, and it is obliged to act in accordance with their complaints, without having the right according to Article 35 para. 1. Of Convention to reject as inadmissible, because they "have not exhausted all means available in their country."

To provide effective protection of fundamental human rights and to avoid the negative consequences that may arise to the state if the citizens in a large address the European Court for Human Rights, the Republic of Macedonia should take appropriate measures in order to improve the efficiency of the courts. In this regard, positive effects are expected to change the legal framework of Procedure, the Law on Civil Procedure, Law on non-contentious procedure, and the Law on execution, and by the latter it was set the new execution (as a measure of systemic reform that the state launched in order to delay preventive procedures). Measures that can be undertaken with the aim of reducing the civil proceedings include:

- Giving priority to the principle written in the first instance procedure could avoid delaying the procedure, (no submissions can be made orally on the record before the court);

- Making space for the action of the individual judge. Not to limit his action, allow him he act in all cases, and the trial court only in cases specified by law. In this context, could be avoided the preliminary hearing;

- Application of mediation, alternative dispute resolution, would lead to the removal of the courts from the large number of cases;

- Consistent implementation of the Law on court fees would affect the development of measures which along with regular tools would help the state budget to cover the material costs of the courts;

- Computerization of courts and judicial training on the use of computers.

- Given the positive experiences of countries which have their own legal system have installed constitutional claim as a procedural instrument for the protection of individual human rights and the need to ensure a greater degree of protection of rights and freedoms, it is time that the Constitutional Court of the Republic of Macedonia, to begin to think about expansion of powers in the sphere of protection of rights and freedoms guaranteed by the Constitution, as it is more than evident the contemporary trend, according to which legal systems are not limited only to a means of protecting the rights and freedoms of the citizens, but define more procedural tools. Setting constitutional claim an additional legal tool for the protection of the right for trial within a reasonable time, would create more opportunities for people who claim that their right were violated.

- To finally depolitize judiciary and ensure its independence from political influences other powers.

\section{Conclusion}

The application of paragraph 1 of Article 6 of the European Convention on Human Rights in the judicial system of the Republic of Macedonia still faces difficulties. The European Court of Human Rights has concluded that the trial within a reasonable time still remains the most common basis for the violation for what which the citizens of RM's appeal to the European Court. Indeed, in recent years there have been some steps taken towards improving the situation, and the first in the legislative and later at the technical and operational plan. The Law on Changes and Amendments to the Law on Courts, unlike its predecessor, could to put in function the legal tools by which parties may seek judicial protection of the right for trial within a reasonable time directly before domestic courts.

By virtue of this law, the rules and principles of the European Convention as well as in the practice of the European Court of Human Rights, the Supreme Court of the Republic of Macedonia began to process the requests of the parties which required protection of the right for trial within reasonable time. In early 2009, the Supreme Court passed merit decisions, which estimated the length of the proceedings, and for parties involved determed cash compensation. An optimistic forecast will give us the right to assume, that if the new legal tool for the protection of the right for trial within a reasonable time frame, installed with the Law on Changes and Amendments to the Law on Courts (2008), is accepted and regarded as efficient by the European Court, it will result in a gradual reduction in the number of complaints of the citizens of the Republic of Macedonia before the European Court. While this does not happen the citizens of the Republic of Macedonia will continue to address their complaints to the Court in Strasbourg for violations of the right for trial within a reasonable time frame. 
The RM concrete measures are being taken to protect the rights set out in the Convention, particularly the right for trial within a reasonable time. First, should be expected results of the implementation of laws by courts which are available to the parties, because their efficient implementation in practice can affect systematic reduction of cases of violation of the principle of trial within a reasonable time. However, this problem should not be seen as separate, but always in the context of the overall reform of the judicial system in RM.

\section{References}

Elijash, M. (2006). Pravo na suđenje u razumnom roku. Zagreb.

Karakamisheva, T. (2007). Analiza za potrebata na voveduvanje ustavna zhalba (tuzhba) vo Republika Makedonija Praven Resursen Centar. Skopje.

Milutinoviç, L. (2004). Suđenje u okviru Razumnog Vremenskog roka. Pravni Informator, Beograd br.11.

Radoloviç, A. (2008). Zashtita prava na suđenje u razumnom roku. Zbornik pravnog fakulteta Sveuçilishte u Rijeci, br.1.

Hans D. Jarass-Bodo, P. (2009). Grundgesetz für die Bundesrepublik Deutschland. Kommentar. Beck. 10. Auflage

Kushtetuta e Republikës së Maqedonisë (Gazeta Zyrtare nr. 52/91, amendamentet e publikuara në Gazetën Zyrtare nr. 1/92, 31/98, 91/01, 84/03 dhe 107/05.

Ligji për gjykatat ("Gazeta zyrtare e RM" nr. 58/2006 dhe 35/2008).

Ligji për procedurën kontestimore (“Gazeta zyrtare e RM” nr. 79/2005).

Kushtetuta e Republikes së Shqipërisë, miratuar me ligjin nr.8417, datë 21.10.1998 dhe e azhurnuar me: 9675/07 dhe 9904/08.

Ustaven zakon na Ustaven sud na Republika Hrvatska (Narodne novine br.31/91; br.49/02).

Grundgesetz für die Bundesrepublik Deutschland vom 23. Mai 1949 (BGBl. S. 1), zuletzt geändert durch Artikel 1 des Gesetzes vom 19. März 2009 (BGBl. I S. 606).

Legge Pinto, $\mathrm{nr} .89 / 2001$.

Konventa Evropiane për mbrojtjen e të drejtave dhe lirive themelore të njeriut e miratuar nga Këshilli i Evropës në vitin 1950.

Raport vjetor për gjendjen e lëndëve kundër Republikës së Maqedonisë për vitin 2012, Shkup, mars 2012).

Strateshki plan na ministerstvoto za pravda, 2012-2014, septemvri 2011. Retrieved from http://www.pravda.gov.mk

\section{Notes}

Note 1. Law on Courts ("Official Gazette of RM" no. 58/2006 and 35/2008), Article 6, para. 2.

Note 2. Civil Procedure Law ("Official Gazette of RM" no. 79/2005), Article 10, para. 1.

Note 3. Strateshki plan na ministerstvoto za pravda 2012-2014, septemvri, 2011.

Note 4. Elijash Marko, Pravo na suđenje u razumnom roku, Zagreb, 2006, fq.17.

Note 5. Milutinoviç Ljubica, Suđenje u okviru Razumnog Vremenskog roka, pravni Informator, br.11/2004, Beograd, fq.64.

Note 6. Milutinoviç Ljubica, Suđenje u okviru Razumnog Vremenskog roka, pravni Informator, br.11/2004, Beograd, fq 63.

Note 7. Ibidem, pg, 64.

Note 8. Radoloviç Aldo, Zashtita prava na suđenje u razumnom roku, Zbornik pravnog fakulteta Sveuçilishte u Rijeci, br.1 (2008), fq. 7.

Note 9. The German law practices determination of exact terms. Thus, at the behest of the German Ministry of Justice, dated 26.08.2005, it is set the length of 4, 4 months in the first instance trial and 7.1. month in the second instance.

Note 10. Article 118, para. 1, Constitution of Macedonia (Official Gazette no. 52/91, amendments published in the Official Gazette no. 1/92, 31/98, 91/01, 84/03 and 107/05. 
Note 11. Freedom of belief, conscience, thought and public expression of opinion, of association and political action and the prohibition of discrimination against citizens on the basis of gender, race, religion, nationality, social and political.. The Constitution should not have a selective approach, in terms of the rights and freedoms by the Constitutional Court, ie should not only protect certain rights and freedoms, but should provide legal protection for all human rights and freedoms either through the Constitutional Court, and the through Basic Courts.

Note 12. Constitutional lawsuit is an instrument for the protection of the individual rights of citizens, which can turn on every citizen who considers that a decision brought by the local judicial, administrative, or other bodies exercising public authority has violated a right guaranteed by the Constitution.

Note 13. Considering the positive experiences of countries which in their own legal system have installed constitutional claim as procedural individual instrument for the protection of individual human rights and the need to ensure a greater degree of protection of rights and freedoms ,it is time that the Constitutional Court of the Republic of Macedonia, to begin to think about expansion of powers in the sphere of protection of rights and freedoms guaranteed by the Constitution, as it is more than evident the contemporary trend according to which legal systems are not limited to just one tool to protect the rights and freedoms of citizens, but define more procedural tools.

Note 14. Mark W. Janis- Richard S. Kay-Anthony W. Bradley, The international law of human rights, Pristina, 2002, p. 522.

Note 15. Karakamisheva Tanja, “Analiza za potrebata na voveduvanje ustavna zhalba (tuzhba) vo Republika Makedonija”, Praven Resursen Centar, Skopje, 2007, fq. 7.

Note 16. Neni 93, paragr. 4a, Grundgesetz für die Bundesrepublik Deutschland vom 23. Mai 1949 (BGB1. S. 1), zuletzt geändert durch Artikel 1 des Gesetzes vom 19. März 2009 (BGB1. I S. 606) According to the German Constitution (GG or GrundG) which came into force on 23.05.1949, constitutional petition before the Constitutional Court, may be submitted only to final decisions and once they have exhausted all other measures provided in the national legal so it has helping character. Hans D. Jarass-Bodo Pieroth: Grundgesetz für die Bundesrepublik Deutschland. Kommentar. Beck. 10. Auflage 2009. Hans D. Jarass-Bodo Pieroth: Grundgesetz für die Bundesrepublik Deutschland. Kommentar. Beck. 10. Auflage 2009.

Note 17 . On the contrary, the issue of Italian law right to a trial within a reasonable time is regulated by a special law, Legge Pinto, No. .89/2001.

Note 18. For more see at.: Karakamisheva Tanja „Analiza za potrebata na voveduvanje ustavna zhalba (tuzhba) vo Republika Makedonija“" Praven Resursen Centar, Skopje, 2007, fq. 7.

Note 19. The right to constitutional petition provided for in the Constitution of the Republic of Albania, approved by Law No. 8417, dated 21.10.1998 and updated with: 9675/07 and 9904/08 (Article 131. Paragraph f.), Under which Constitutional Court decides on the final adjudication of individual complaints for violation of their constitutional rights to a fair trial, after having exhausted all instruments for the protection of these rights.

Note 20. Article 3, Law on changes and amendments to the Law on Courts, Official Gazette of RM nr.35/2008. Ibid, Article 36, para. 1.

Note 21. Ibidem, article 36, paragr. 1.

Note 22. Article 5, para., 1Ligji on amendments to the Law on Courts, Official Gazette of RM nr.35/2008.

Note 23. Law on Changes and Amendments of the Law on Courts, Official Gazette of RM nr.35/2008, Article 4, para.4.

Note 24. Ibidem, article 4, para. 5.

Note 25. Ibidem, article 5, para. 3.

Note 26. The Constitution of the Republic of Macedonia (Official Gazette no. 52/91, amendments published in the Official Gazette no. 1/92, 31/98, 91/01, 84/03 and 107/05.

Note 27. Article 3 and 5, paragr.1 European Convention on human rights and fundamental freedoms.

Note 28. Milutinoviç Ljubica, Suđenje u okviru Razumnog Vremenskog roka, pravni Informator, br.11/2004, Beograd.

Note 29. Bajallxhiev against Republic of Macedonia, Nr.4650/06, 25.10.2011 (information taken from Internet http://www.pravda.gov.mk). 
Note 30. Godishen izveshtaj za sostojbata na predmeti protiv Republika Makedonija pred Evropskiot sud za çovekovi prava za 2012 godina, Skopje, mart 2012.

Note 31. European Convention for the protection of human rights and fundamental freedoms, 1950, Article 38. para. 1.

Note 32. Case: Janeva against Republic of Macedonia, Nr. 58185/00, 03.10.2002. (information from Internet http://www.pravda.gov.mk).

Note 33. Godishen izveshtaj za sostojbata na predmeti protiv Republika Makedonija pred Evropskiot sud za çovekovi prava za 2012 godina, Skopje, mart 2012.

Note 34. www.pravda.gov.mk/doc

Note 35. Law on Courts, (Official Gazette of RM "no. 58/2006 and 35/2008).

\section{Copyrights}

Copyright for this article is retained by the author(s), with first publication rights granted to the journal.

This is an open-access article distributed under the terms and conditions of the Creative Commons Attribution license (http://creativecommons.org/licenses/by/3.0/). 